\title{
Dorsal root entry zone lesions (Nashold's procedure) for pain relief following brachial plexus avulsion
}

\author{
DGT THOMAS, JPR SHEEHY
}

From the Gough Cooper Department of Neurological Surgery, Institute of Neurology, the National Hospital for Nervous Diseases, Queen Square, London, UK

SUMMARY Brachial plexus. avulsion is an important cause of severe intractable pain, particularly in young motor cyclists. The pain usually develops soon after the injury. In a minority of cases severe pain persists and is refractory to management. Nineteen patients are reviewed in whom dorsal root entry zone lesions have been produced for pain relief. The operative technique is described. Early post-operative motor or sensory disturbance in the ipsilateral leg have been temporary side effects, with mild persisting deficits in a minority. Sixteen cases have had significant persisting pain relief. The maximum follow-up period is $2^{1 / 2}$ years.

Brachial plexus avulsion is an important cause of severe intractable pain, particularly in young motor cyclists. Such pain occurs in the flail, deafferented, limb shortly after injury and in the majority of cases settles to tolerable levels spontaneously, or on drug treatment with non-narcotic analgesics. However, in a minority of cases the pain persists and may worsen over a period of years. ${ }^{1}$ This type of severe chronic pain has proved particularly resistant to treatment with several pain control procedures, including stellate ganglion blockade, sympathectomy, cordotomy, rhizotomy, amputation, transcutaneous stimulation, dorsal column stimulation and analgesic drugs including narcotics.

Nashold et al in $1976^{2}$ first described the procedure of intraspinal coagulation of the dorsal root entry zones of the avulsed roots, performed at laminectomy, as a treatment for this type of pain.

\section{Patients}

There were 19 patients in this series of partial or complete brachial plexus avulsion. Seventeen were male and two female. Clinical features of the patients with avulsion injury are tabulated in the table. Fifteen cases developed their injuries following a motor cycle accident. In 16 cases the lesion was on the right. Ten cases concurrently sustained head injuries rendering them unconscious. One case required urgent laparotomy and splenectomy. The onset of

Address for reprint requests: Mr DGT Thomas, the National Hospital for Nervous. Diseases, Queen Sq, London WC1N 3BG, UK.

Received 7 April 1983. Accepted 14 May 1983 the pain was usually within days of sustaining the brachial plexus avulsion injury. However, the longest interval between brachial plexus avulsion and the onset of pain was two years. The pain was characteristically felt as a crushing or burning sensation in the deafferentated limb. It was not $\mathbb{D}$ usually in a sharply defined dermatomal distribution, but $\frac{\rho}{\Phi}$ rather tended to be experienced globally, throughout the $\varrho$ arm, either proximally or distally in the limb. In many cases the pain was constant, though episodic severe exacerbations of sharp pain were commonly noted. All these cases had had no sustained response to other pain procedures, $\preceq$ which included stellate ganglion blockade, cordotomy, amputation, transcutaneous, dorsal column, or mid-brain stimulation as well as analgesic drugs, including narcotic analgesics.

The diagnosis and evaluation of brachial plexus avulsion injuries have been discussed extensively in the literature..$^{3-10}$ Varying degrees of motor paralysis were present. A completely fiail extremity was the most common finding, with sensory loss usually involving the whole upper limb to the shoulder. An ipsilateral Horner's syndrome was found in seven cases. Three of the patients had undergone amputation of the involved limb without improvement. Cordotomy was used in one case without relief. The majority of cases had had transcutaneous stimulation without sustained improvement. Most patients had tried a wide range of analgesics and found the relief so small they had ceased taking them, as has been noted in other series.' Eighteen cases had stellate ganglion blocks without sustained effect.

The myelographic sign of traumatic pseudomeningocele was initially described by Murphey $e$ al $^{11}$ in patients with brachial plexus avulsion. Myelography has been performed on all our cases prior to surgery. Cord displacement, root avulsion and pseudomeningocele formation have been demonstrated in varying combinations in all cases (figs 1 , 2). The extent of root avulsion seen at operation has frequently been more extensive than has been demonstrated myelographically, as has been noted by other authors.5 710 12-14 1618 
Table Pain following brachial plexus avulsion: data in 19 patients managed by dorsal root entry zone (DREZ) thermocoagulation

\begin{tabular}{|c|c|c|c|c|c|c|c|c|c|}
\hline $\begin{array}{l}\text { Case } \\
\text { No. }\end{array}$ & $\begin{array}{l}\text { Sex } \\
\text { Age } \\
(y r)\end{array}$ & Trauma & $\begin{array}{l}\text { Clinical } \\
\text { findings }\end{array}$ & $\begin{array}{l}\text { Treatment prior } \\
\text { to DREZ }\end{array}$ & & $\begin{array}{l}\text { Pain } \\
\text { relief } \\
\text { afier } \\
\text { DREZ }\end{array}$ & $\begin{array}{l}\text { Follow } \\
\text { up } \\
\text { (months) }\end{array}$ & $\begin{array}{l}\text { Motor } \\
\text { weakness }\end{array}$ & $\begin{array}{l}\text { Sensory } \\
\text { s change }\end{array}$ \\
\hline 1 & $\begin{array}{l}M \\
29\end{array}$ & $\begin{array}{l}1968 \text { motorcycle. } \\
\text { Right brachial } \\
\text { plexus avulsion }\end{array}$ & $\begin{array}{l}\text { Total paralysis right arm. } \\
\text { Arm pain. }\end{array}$ & TCS Narcotic analgesics & & Good & 32 & + & - \\
\hline 2 & $\begin{array}{l}\mathbf{M} \\
\mathbf{3 2}\end{array}$ & $\begin{array}{l}1976 \text { motorcycle. } \\
\text { Head Injury. Right } \\
\text { brachial plexus avulsion }\end{array}$ & $\begin{array}{l}\text { Right Horner's syndrome. } \\
\text { Right arm pain. } \\
\text { Right arm weakness. }\end{array}$ & $\begin{array}{l}\text { Mid-arm amputation, } \\
1978 \text { for pain. } \\
\text { TCS }\end{array}$ & No relief & Good & 30 & + & - \\
\hline 3 & $\begin{array}{l}M \\
42\end{array}$ & 1959 pedestrian hit by car & $\begin{array}{l}\text { Paralysis right arm. } \\
\text { Pain developed two } \\
\text { years after accident. }\end{array}$ & $\begin{array}{l}1962 \text { arm amputated for pain. } \\
\text { Hypnosis. } \\
\text { Faith healing. } \\
1973 \text { Cordotomy. TCS }\end{array}$ & No relief & Fair & 22 & + & + \\
\hline 4 & $\begin{array}{l}M \\
27\end{array}$ & $\begin{array}{l}1979 \text { Driver in road } \\
\text { traffic accident. } \\
\text { Brachial plexus avulsion }\end{array}$ & $\begin{array}{l}\text { Right Horner's syndrome. } \\
\text { Pain in right hand since } \\
\text { accident. Distal right arm } \\
\text { weakness. Mild weakness } \\
\text { right leg. }\end{array}$ & $\begin{array}{l}\text { Stellate ganglion } \\
\text { blockade. } \\
\text { TCS }\end{array}$ & No relief & Fair & 20 & - & - \\
\hline 5 & $\begin{array}{l}\mathbf{M} \\
\mathbf{3 3}\end{array}$ & $\begin{array}{l}1979 \text { motorcycle. } \\
\text { Brachial plexus avulsion. } \\
\text { Head Injury. } \\
\text { Temporal lobe epilepsy. } \\
\text { Multiple long bone } \\
\text { fractures. }\end{array}$ & $\begin{array}{l}\text { Right Horner's syndrome. } \\
\text { Flail right arm. Right } \\
\text { arm pain after regaining } \\
\text { consciousness. }\end{array}$ & $\begin{array}{l}\text { Plexus exploration. } \\
\text { Stellate ganglion } \\
\text { blockade. TCS }\end{array}$ & No relief & Good & 19 & - & - \\
\hline 6 & $\begin{array}{l}M \\
60\end{array}$ & $\begin{array}{l}1980 \text { Motorcycle. } \\
\text { Brachial plexus avulsion. }\end{array}$ & $\begin{array}{l}\text { Right Horner's syndrome. } \\
\text { Flail right arm. Pain in } \\
\text { right arm soon after } \\
\text { accident. }\end{array}$ & $\begin{array}{l}\text { TCS Medication. } \\
\text { Analgesics }\end{array}$ & No relief & Poor & 19 & - & - \\
\hline 7 & $\begin{array}{l}\mathbf{F} \\
32\end{array}$ & $\begin{array}{l}1980 \text { Motorcycle pillion } \\
\text { passenger. Minor head } \\
\text { injury. Brachial plexus } \\
\text { avulsion. }\end{array}$ & $\begin{array}{l}\text { Right Horner's syndrome. } \\
\text { Flail right arm. Pain in } \\
\text { right hand and forearm. }\end{array}$ & $\begin{array}{l}\text { Narcotic analgesics. } \\
\text { TCS }\end{array}$ & $\begin{array}{l}\text { No rehief } \\
\text { Temporary } \\
\text { relief } \\
\text { (days) }\end{array}$ & Fair & 18 & - & - \\
\hline 8 & $\begin{array}{l}M \\
21\end{array}$ & $\begin{array}{l}1978 \text { Motorcycle. } \\
\text { Head injury. } 10 \text { days } \\
\text { unconscious. Brachial } \\
\text { plexus avulsion. } \\
\text { Multiple long bone } \\
\text { fractures. }\end{array}$ & $\begin{array}{l}\text { Fail right arm. Aware of } \\
\text { pain from moment of } \\
\text { consciousness. }\end{array}$ & $\begin{array}{l}\text { TCS } \\
\text { narcotic analgesic }\end{array}$ & $\begin{array}{l}\text { No relief } \\
\text { Partial } \\
\text { relief }\end{array}$ & Fair & 18 & - & - \\
\hline 9 & $\begin{array}{l}M \\
43\end{array}$ & $\begin{array}{l}1978 \text { Motorcycle. } \\
\text { Head injury. Splenic } \\
\text { rupture. }\end{array}$ & $\begin{array}{l}\text { Right Horner's syndrome. } \\
\text { Flail right arm. Pain } \\
\text { developed } 3 \text { weeks after } \\
\text { accident. }\end{array}$ & $\begin{array}{l}\text { Stellate ganglion } \\
\text { blockade. TCS }\end{array}$ & No relief & Poor & 18 & - & - \\
\hline 10 & $\begin{array}{l}M \\
60\end{array}$ & $\begin{array}{l}1979 \text { following surgery to } \\
\text { right shoulder, developed } \\
\text { distal right arm weakness. }\end{array}$ & $\begin{array}{l}\text { Pain in right forearm } \\
\text { and hand. Clawing right } \\
\text { hand. Weakness distally } \\
\text { in right arm. Right C8- } \\
\text { D2 pin loss. Right triceps } \\
\text { jerk absent. }\end{array}$ & $\begin{array}{l}\text { Narcotic analgesics. } \\
\text { TCS }\end{array}$ & $\begin{array}{l}\text { Minimal } \\
\text { relief } \\
\text { No relief }\end{array}$ & Poor & 16 & + & - \\
\hline 11 & $\begin{array}{l}F \\
65\end{array}$ & $\begin{array}{l}1977 \text { Pedestrian road } \\
\text { traffic accident. } \\
\text { Left shoulder fracture. } \\
\text { Brachial plexus avulsion. }\end{array}$ & $\begin{array}{l}\text { Pain in the fingers and } \\
\text { hand. Flail left arm. }\end{array}$ & $\begin{array}{l}\text { TCS } \\
\text { Guanethidine block } \\
\text { Narcotic analgesic }\end{array}$ & $\begin{array}{l}\text { No relief } \\
\text { Minimal } \\
\text { relief }\end{array}$ & Good & 16 & - & - \\
\hline & & $\begin{array}{l}\text { Head injury, unconscious } \\
3 \text { hours. }\end{array}$ & & Arthrodesis left shoulder & No relief & & & & \\
\hline 12 & $\begin{array}{l}M \\
36\end{array}$ & $\begin{array}{l}1972 \text { Motorcycle. } \\
\text { Unconscious } 3 \text { days. } \\
\text { Right brachial plexus } \\
\text { avulsion. }\end{array}$ & $\begin{array}{l}\text { Flail right arm. Pain in } \\
\text { arm and elbow. }\end{array}$ & TCS Medication & No relief & Good & 15 & + & - \\
\hline 13 & $\begin{array}{l}\mathbf{M} \\
27\end{array}$ & $\begin{array}{l}1980 \text { Motorcycle. } \\
\text { Unconscious for } 3 \text { days. } \\
\text { Brachial plexus avulsion }\end{array}$ & $\begin{array}{l}\text { Flail right arm. Pain in } \\
\text { lateral arm and medial } \\
\text { forearm. Suicidal. }\end{array}$ & $\begin{array}{l}\text { Stellate ganglion } \\
\text { block. TCS Medication }\end{array}$ & No relief & Fair & 15 & - & + \\
\hline 14 & $\mathbf{M}$ & $\begin{array}{l}1959 \text { Motorcycle. } \\
\text { Brachial plexus avulsion. }\end{array}$ & $\begin{array}{l}\text { Right Horner's syndrome. } \\
\text { Flail right arm: Burning } \\
\text { pain in right arm and } \\
\text { hand. }\end{array}$ & $\begin{array}{l}\text { Acupuncture } \\
\text { Peri-aqueduct gray } \\
\text { matter stimulation } \\
\text { removed for sepsis }\end{array}$ & $\begin{array}{l}\text { Relief for } \\
3 \text { weeks } \\
\text { Minimal }\end{array}$ & Good & 14 & - & - \\
\hline 15 & $\begin{array}{l}M \\
49\end{array}$ & $\begin{array}{l}1958 \text { Motorcycle. } \\
\text { Brachial plexus avulsion }\end{array}$ & $\begin{array}{l}\text { Pain since accident in } \\
\text { right arm. Flail right arm. }\end{array}$ & $\begin{array}{l}\text { Sympathetic blockade. TCS } \\
\text { Medication }\end{array}$ & No relief & Fair & 14 & - & + \\
\hline 16 & $\begin{array}{l}M \\
\mathbf{M}\end{array}$ & $\begin{array}{l}1970 \text { Motorcycle. } \\
\text { Brachial plexus avulsion. } \\
\text { Head injury. }\end{array}$ & $\begin{array}{l}\text { Pain developed } 1 \text { year } \\
\text { after injury in lower } \\
\text { forearm and elbow. } \\
\text { Flail left arm. }\end{array}$ & $\begin{array}{l}\text { Stellate ganglion blockade. } \\
\text { TCS }\end{array}$ & $\begin{array}{l}\text { No relief } \\
\text { Relief for } \\
\text { days }\end{array}$ & Good & 14 & - & - \\
\hline 17 & $\begin{array}{l}\mathrm{M} \\
52\end{array}$ & $\begin{array}{l}1951 \text { Motorcycle. } \\
\text { Brachial plexus avulsion. } \\
\text { Head injury. }\end{array}$ & $\begin{array}{l}\text { Flail right arm. Pain } \\
\text { present since accident as a } \\
\text { burning sensation in right } \\
\text { forearm with occasional } \\
\text { shooting pain. }\end{array}$ & $\begin{array}{l}\text { Stellate blockade } \\
\text { DCS. TCS }\end{array}$ & No relief & Good & 13 & + & + \\
\hline
\end{tabular}


(Table, continued)

18 M 1978 Motorcycle

23 Head injury. Left

brachial plexus avulsion.

Pain commenced in flail TCS Medication

limb 2 weeks after the

TCS Medication

accident. Burning in

nature.

19 M 1967 Motorcycle.

36 Unconscious 6 hrs.

Right brachial plexus

Pain developed in flail

1969 mid-arm amputation.

limb soon after recovering Non-narcotic analgesics.

consciousness. Unable to TCS

avulsion

work because of pain.

+TCS-Transcutaneous stimulation

-DCS-Dorsal column stimulation

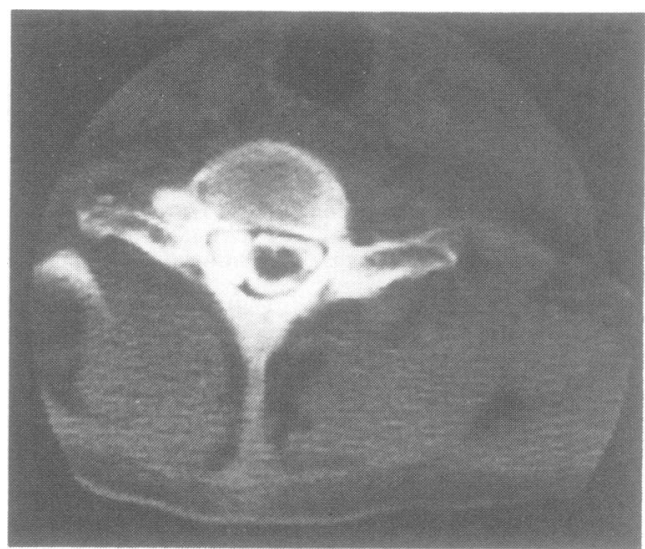

Fig 2 Metrizamide CT scan demonstrating

pseudo-meningocele within the canal extending into the intervertebral foramen associated with hemi-atrophy of the cord and displacement of the spinal cord towards the opposite side.

\section{Operative method}

The technique of lesion making has been described by Nashold $e t$ al. ${ }^{214}$ is A laminectomy is performed from C5/ D1. It has been found most satisfactory to position the patient prone. The dura is opened and the intermediolateral sulcus of the spinal cord, adjacent to the dorsal column, is identified by inspection and palpation with a dissector under the operating microscope. The sulcus not infrequently is difficult to identify. In such cases reference is made to the attached root on the uninjured side in order to visualise the line of the sulcus. A degree of local hemiatrophy of the cord is common. In a minority of cases an incomplete root avulsion is noted on the injured side. Such attached roots can be especially useful in identifying the line of the sulcus. The electrode used to produce the lesion is an insulated steel wire, $0.5 \mathrm{~mm}$ in diameter, with an uninsulated $2 \mathrm{~mm}$ tapered tip. (Thermocouple electrode TCS Radionics Inc, Burlington, Mass, USA). The elec-
Fig 1 Metrizamide myelography demonstrating pseudo-meningocele formation and root avulsion on the left over the brachial plexus outflow with displacement of the cord to the right. 
trode is introduced by hand into the dorsal root entry zone at the intermedio-lateral sulcus, adjacent to the dorsal column, at the point where the dorsal roots have been avulsed. The electrode is angled medially at approximately $25^{\circ}$ to the sagittal plane and inserted into the cord for a distance of $2 \mathrm{mms}$. The lesion is produced using a thermocoagulation radio frequency generator (RGF-5 with thermocouple adaptor TCA-1, Radionics Inc. Burlington, Mass, USA), controlled to deliver $\mathbf{4 0}$ milliamperes for $\mathbf{1 5}$ seconds. Lesions are spaced at $2 \mathrm{~mm}$ intervals, ${ }^{14}$ and typically 20 to 24 are required over the brachial plexus outflow C5/D1.

\section{Results}

Three levels of pain relief were defined: a good result signified $75 \%$ or greater relief of pain; a fair result, defined as pain relief of 25-75\%; a poor result means relief of less than $25 \%$. The results are tabulated in the table. By these criteria 11 cases have had a persisting good improvement, and a further five cases have had a fair result. Patients have commonly noted a slight deterioration in pain relief in the early post-operative months to a level that has then persisted over the period of follow-up. Six cases have been followed for more than 18 months. There have been three good results, two fair and one poor result from this group. In two patients (cases 6 and 10) an initial good result was obtained but after a few months the result became poor.

In 10 patients there was some initial postoperative deterioration in motor or sensory function of the ipsilateral leg (table). The motor deficit has generally been mild although it was marked in case 1. The most common sensory change has been a proprioceptive deficit. The sensory and motor signs have improved in all cases, although in a minority signs persist. All the patients are ambulant.

\section{Discussion}

An increasing number of young men are sustaining traction lesions of the brachial plexus ${ }^{1}$ commonly due to motor cycle accidents. Wynn-Parry, ${ }^{1}$ in his review of 108 cases of post-traumatic brachial plexus lesions proximal to the dorsal root ganglion, noted pain was present in 98 in the affected limb. In $25 \%$ pain was severe after four years and in $17 \%$ the pain was still severe 11 years after injury. In a small, but significant, minority of cases severe pain persists and is refractory to medical and surgical therapy with drugs, stimulation, cordotomy and amputation. The onset of pain has usually been within weeks of the injury although in case 16 the onset was one year, and in case 3 the onset was two years, from the time of injury.

Several theories have been postulated to explain the mechanism of central pain. Three of these theories may be most applicable in elucidating the pathophysiological changes in the spinal cord responsible for the avulsion pain. The first is that hypersensitive neuronal pools exist in the injured dorsal root entry zone, due to deafferentation. The second is that dysfunction of the neurons of the dorsal root entry zone occurs due to facilitatory or inhibitory influences of the tract of Lissauer. The third theory postulates injury to the spinothalamic or the spino-reticular pain pathways.

Loeser and Ward ${ }^{20}$ have shown the effects of deafferentation after the division of the dorsal root in cats. Using microelectrodes they recorded discharges in the dorsal horn. They found the discharges may take up to $\mathbf{3 0}$ days to reach their peak and that they are in two forms: a continuous background discharge with occasional bursts of high frequency. These findings would correlate well with the clinical situation in which many patients have continuous pain with episodes of sharp exacerbation. The abnormal discharges may be conducted centrally in the spino-thalamic or spino-reticular pathways, whose cells of origin are, to some extent, in the dorsal root entry zone. The effect of the lesions may be to interfere with this transmission. The tract of Lissauer ${ }^{21}$ lies in the apex of the dorsal horn and extends throughout the length of the spinal cord. Ranson $^{22}$ has suggested the importance of this tract in the central conduction of pain and temperature. Between one third and half of the fibres in the tract are dorsal root afferent fibres which run in the tract for 1 to 3 segments in both rostral and caudal directions. The remaining fibres are the axons of dorsal horn neurons; the total span of these fibres is not clear but estimates range between a few millimetres and 5 to 6 segments. ${ }^{23}$ The surgical lesions may produce pain relief by influencing the local connections of the tract in the substantia gelantinosa. Opiate receptors have been shown to be present in high density in the marginal cell zone and the substantia gelatinosa of the dorsal horn of the spinal cord in rats, ${ }^{24}$ using autoradiographic localisation. Lamotte et $a l^{25}$ have reported a fall of opiate receptor binding following dorsal root section using a similar technique.

Further understanding of the exact neuroanatomical and neurophysiological changes produced by the dorsal root entry zone lesion will reduce the morbidity of the procedure and clarify its mode of action. Intraoperative monitoring of somatosensory evoked potentials may make localisation of the dorsal root entry zone more accurate and minimise the possibility of damage to the adjacent long tracts.

Sixteen of 19 patients with severe chronic pain due to brachial plexus avulsion, which had proved 
refractory to other treatment, were successfully treated by dorsal root entry zone lesions. There was early morbidity in 10 patients, but significant persisting disability was found in only two cases, both of whom remained ambulant. In patients with severe, disabling, pain, intractable to other treatment, dorsal root entry zone lesions are indicated as the optimal lesional method of management with an acceptable morbidity in this selected patient population.

A preliminary report concerning the first 15 of these cases was presented at the Centennial Meeting of the Society of British Neurological Surgeons at Cork in March-April 1982. ${ }^{26}$ We are grateful to Dr Wynn Parry, Director of the Rehabilitation Centre, Stanmore who assessed and referred most of these cases.

\section{References}

1 Wynn-Parry CB. Pain in avulsion lesions of the brachial plexus. Pain 1980;9:41-53.

${ }^{2}$ Nashold BS Jr, Urban B, Zorub DS. Phantom relief by focal destruction of substantia gelatinosa of Rolando, In: Bonica JJ, Albe-Fessard D (ed): Advances in Pain Research and Therapy. New York: Raven Press 1976;1:959-63.

${ }^{3}$ Bonney G. Watson-Jones lecture 1976 . Some lesions of the brachial plexus. Ann $R$ Coll Surg Engl 1977;59:298-306.

${ }^{4}$ Landi A, Copeland S, Wynn Parry CB, Jones S. The role of somatosensory evoked potentials and nerve conduction studies in the surgical management of brachial plexus injuries. J Bone Joint Surg (Br) 1980; Nov 62 B(4):492-6.

${ }^{5}$ Leffert RD. Brachial plexus injuries. $N$ Engl $J$ Med 1974;291:1059-67.

${ }^{6}$ Millesi H. Surgical Management of brachial plexus injuries. J Hand Surg 1977;2:367-79.

${ }^{7}$ Robles J. Brachial plexus avulsion. A review of diagnostic procedures and report of six cases. J Neurosurg 1968;28:434-8.

${ }^{8}$ Seddon H. Surgical Disorders of the Peripheral Nerve. Baltimore: Williams and Wilkins 1972:183-96.

${ }^{9}$ Warren J, Gutmann L, Figueroa AFJ, et al. Electromyographic changes of brachial plexus root avulsion. $J$ Neurosurg 1969;31:137-40.
${ }^{10}$ Zorub DS, Nashold BS Jr, Cook WA Jr. Avulsion of the brachial plexus. 1. A review with implications on the therapy of intractable pain. Surg Neurol 1974;2:347-53.

"Murphey F, Hartung W, Kirlin JW. Myelographic demonstration of avulsing injury of the brachial plexus. Am J Roentgenol 1947;58:102-5.

${ }^{12}$ Kewairamani LS, Taylor RG. Brachial plexus root avulsion: role of myelography. Review of diagnostic procedures. J Trauma 1975;15:603-8.

${ }^{13}$ Mendelsohn RA, Weiner IH, Keegan JM. Myelographic demonstration of brachial plexus root avulsion. Arch Surg 1957;75:102-7.

14 Nashold BS, Ostdahl RH. Dorsal root entry zone lesions for Pain Relief. J Neurosurg 1979;51:59-69.

${ }_{15}$ Nashold BS. Technical note. J Neurosurg 1981;55:1012.

${ }^{16}$ Rayle AA, Gay BB, Meadors JL. The myelogram in avulsion of the brachial plexus. Radiology 1955;65:65-72.

${ }^{17}$ Sunderland S. Mechanisms of cervical nerve root avulsion in injuries of the neck and shoulder.J-Neurosurg 1974;41:705-14.

18 Taylor PE. Traumatic intradural avulsion of the nerve roots of the brachial plexus. Brain 1962;85:579-602.

19 Bonney G. Prognosis in traction lesions of the brachial plexus. J Bone Joint Surg 1959;41B:4-35.

${ }^{20}$ Loeser JD, Ward AA Jr. Some effects of deafferentation on neurons of the cat spinal cord. Arch Neurol 1967;17:629-36.

${ }^{21}$ Lissauer H. Beitrag zur pathologischen Anatomie der tabes doralis und sum Faserverlauf im menschlichen Ruckenmark. Neurologisches Centralblatt 1885; 4:245-6.

${ }^{22}$ Ranson SW. The course within the spinal cord of the non-medullated fibers of the dorsal roots: A study of Lissauer's tract in the cat. J Comp Neurol 1913;23:259-81.

${ }^{23}$ Cervero F, Iggo A. Substantia gelatinosa of the spinal cord: A critical review. Brain 1980;103:717-72.

24 Atweh SF, Kuhar MJ. Autoradiographic localisation of opiate receptors in rat brain. 1. Spinal cord and lower medulla. Brain Res 1977;124:53-67.

${ }^{25}$ LaMotte C, Pert CB, Snyder SH. Opiate receptor binding in primate spinal cord: distribution and changes after dorsal root section. Brain Res 1976;112:407-12.

${ }^{26}$ Thomas DGT, Sheehy J. Dorsal Root Entry Zone Coagulation (Nashold's procedure) for pain due to brachial plexus avulsion. J Neurol Neurosurg Psychiatry 1982;45:949. 